\title{
Great expectations? evidence from Colombia's exchange rate survey
}

\author{
Juan Jose Echavarria ${ }^{1} \cdot$ Mauricio Villamizar-Villegas $^{1}$ (D)
}

Received: 8 January 2015/ Accepted: 7 July 2016/Published online: 21 July 2016

(c) The Author(s) 2016. This article is published with open access at Springerlink.com

\begin{abstract}
In this paper, we use the largest exchange rate survey in Colombia to test for the rational expectations hypothesis, the presence of a time-varying risk premium and the accuracy of exchange rate forecasts. Our findings indicate that episodes of exchange rate appreciation preceded expectations of further appreciation in the short run, but were marked by depreciations in the long run. This reversal largely explains the stabilizing pattern of expectations. Additionally, we find that the forward discount differed from future exchange rate changes due to the rejection of the unbiasedness condition and to the presence of a time-varying risk premium. Finally, we find that only short run expectations were able to outperform a random walk process as well as models of extrapolative, adaptive, and regressive expectations. Long-run expectations, on the other hand, behaved poorly in terms of forecasting accuracy.
\end{abstract}

Keywords Exchange rate expectations · Risk premium · Forecasting accuracy · Random walk $\cdot$ Forward discount $\cdot$ Rational expectations hypothesis

JEL Codes: C23 , C53, C83 , F31 , F37

We thank Luis Fernando Melo, Sandra Benitez, Behzad Diba, Guido Kuersteiner, Matthew Canzoneri, Martha Lucia Villa, Tatiana Venegas and Maria A. Penuela for comments and discussions. The views expressed herein are those of the authors and not necessarily those of the Banco de la República nor its Board of Directors.

Mauricio Villamizar-Villegas

mvillavi@banrep.gov.co

Juan Jose Echavarria

jechavso@banrep.gov.co

1 Banco de la República, Bogotá, Colombia 


\section{Introduction}

The total currency turnover in global financial markets has dramatically increased since the end of the Bretton Woods system in the early 1970s. In fact, progressive financial innovation and deregulation have induced foreign exchange trading to exceed, by almost 20 -fold, the volume of goods and services worldwide. ${ }^{1}$ According to Jongen et al. (2008), "It therefore seems that the foreign exchange market is a market 'on its own' and that this market, because of its large volume, is highly liquid and efficient." 2 As such, there has been a longstanding debate in the international finance literature on the main factors driving these capital flows. Nonetheless, most of the works agree that expectations play a central role in the determination of the exchange rate and for some authors, little else matters (see Woodford and Walsh (2005)).

Exchange rate expectations are generally assumed to be unbiased, homogeneous, and stabilizing. In many occasions, expectations are also assumed to be risk neutral, which overlooks potential effects brought forth by a time-varying risk premium. Namely, models that incorporate no-arbitrage conditions (such as the uncovered interest rate parity) assume that different currency-denominated assets are perfect substitutes. ${ }^{3}$ Consequently, the validity of results largely depends on the accuracy of these assumptions.

Paradoxically, the empirical literature has shown again and again that these assumptions do not hold. In fact, there is a long history of evidence pioneered by Frankel (1979), Dominguez (1986), and Frankel and Froot (1987) and by more recent works of De Grauwe and Grimaldi (2006) and De Grauwe and Markiewicz (2013) that show a systematic bias in exchange rate expectations. In addition, Ito (1990) and Allen and Taylor (1990) find empirical evidence of strong heterogeneity in expectations among market participants. ${ }^{4}$

There are also numerous studies such as Lewis (1995), Bekaert (1996), Mark and Wu (1998), Carlson (1998), and Meredith and Ma (2002) that find statistical evidence of a currency risk premium. Authors such as Nurkse (1944), Takagi (1991), and Frankel and Rose (1994) consider expectations to be highly volatile and unstable, and state that the influence of psychological factors may at times be overwhelming. They claim that the destabilizing pattern of expectations (commonly known as "bandwagon expectations") produce extremely volatile exchange rates which negatively affect investment and international trade, increase protectionist pressures, and hinder the development of the financial sector.

Notwithstanding, central banks still maintain a high degree of credibility on exchange rate surveys and often use them as input for their own internal forecasts. ${ }^{5}$ They generally argue that the use of ex-post exchange rates as a proxy for

\footnotetext{
1 See the 2013 Triennial Central Bank Survey of the Bank for International Settlements (BIS).

2 Jongen et al. (2008), page 1.

3 See Villamizar-Villegas and Perez-Reyna (2015).

4 Ito (1990) uses biweekly panel data collected by the Japan Center for International Finance. It includes 44 financial institutions. Allen and Taylor (1990) use data from the foreign exchange market in London.

5 See Villamizar-Villegas (2015).
} 
expectations has the disadvantage of assuming rational expectations instead of testing them, that is, studies that employ observed ex-post exchange rates cannot fully determine whether the evidence of a risk premium is in fact attributed to a time-varying risk or to the failure of rational expectations.

In this paper, we use a novel (and proprietary) survey conducted monthly by the Central Bank of Colombia during October 2003-August 2012 to test for the rational expectations hypothesis, the presence of a time-varying risk premium, and the accuracy of exchange rate forecasts. Our dataset (monthly frequency) is by far the largest official exchange rate survey in the country, containing a comprehensive outlook of the financial sector, with responses from nearly all pension funds, stockbrokers, and commercial banks, and while assumptions on exchange rate dynamics have been widely researched in the literature, to our knowledge there is no study applied to the Colombian case. Consequently, we shed light on the validity of several economic assumptions that relate to the nature of exchange rate behavior, using detailed and real-time data on traders, analysts, and market makers.

Our main findings indicate that episodes of exchange rate appreciation preceded expectations of further appreciation in the short run, but were marked by depreciations in the long run. In the related literature, this pattern has been referred to as an expectational twist and partially explains the stabilizing nature of expectations. For example, as explained in Jongen et al. (2008), market participants might be reacting to momentum models in the short run (i.e., chartists), while making use of equilibrium models supported by macroeconomic fundamentals in the long run (i.e., fundamentalists). Additionally, we find that the forward discount differed from future exchange rate changes due to a significant time-varying risk premium, and that both the unbiasedness and orthogonality conditions are rejected for all horizons considered. In line with most of the existing literature, these results constitute ample evidence against the efficient market hypothesis (EMH).

Finally, we set forth five competing strategies to assess how well actual expectations performed, relative to a random walk process. We find that 1-month expectations outperform a random walk process as well as models of extrapolative, adaptive, and regressive expectations. But results are almost the opposite for 1-year forecasts, where expectations do not outperform a random walk. In this last case, traders and analysts answering the survey could have improved their forecasts by incorporating information from the forward discount, past exchange rate changes, policy meetings, or the policy rate.

This paper is organized as follows. Sect. 2 describes the data and investigates the incidence and potential attrition bias due to the number of non-responses within our unbalanced panel. Section 3 reviews the accuracy of forecasts and the relative importance of rational expectations within the purview of the forward premium puzzle. Section 4 presents different models of how expectations are formed and determines their stabilizing or destabilizing nature. This section also compares agents' forecasting accuracy with that of a random walk. Finally, Sect. 5 concludes. 


\section{Data}

\subsection{Survey data}

Survey data have been widely used in the international finance literature. Examples include interest rate surveys to test for term premia as well as surveys containing stock market rates, GNP deflators, and money aggregates. ${ }^{6}$ Additionally, survey data on exchange rates have been widely used to test for rationality and the presence of a risk premium without having to depend on forward rates or ex-post values of exchange rates.

There are, however, obvious drawbacks of using survey data. For one, there is no guarantee that agents will disclose their true beliefs. As mentioned by Frankel and Froot (1987), "It is a cornerstone of positive economics that we learn more by observing what people do in the marketplace than what they say". ${ }^{7}$ In addition, the timing of the forecast report might not coincide with the closing of the exchange rate market, which might give some agents additional hours of information in their predictions. Finally, there can be wide dispersion in the answers provided by market participants. Nevertheless, exchange rate surveys can be less problematic than other surveys (i.e., GDP, prices, etc.) since investors or analysts responding to the survey are actively involved in foreign exchange trading. They at least represent a clear improvement on the conventional methodology of assuming ex-post exchange rates as a proxy for exchange rate expectations.

In the exercises that follow, we use the Central Bank Expectations Survey conducted monthly by the Central Bank of Colombia during October 2003-August 2012. ${ }^{8}$ Specifically, the survey asks for the 1-month, end-of-year and 1-year ahead exchange rate forecasts; where the exchange rate is denoted in units of Colombian pesos per US dollar (COP/USD). In total, 90 surveyed financial institutions were classified into three groups/types: (1) Commercial Banks (median of 15 responses per month out of 34), (2) Stockbrokers (median of 19 responses per month out of 44) and (3) Pension Funds (median of 5 responses per month out of 12). As depicted in Fig. 1, the number of non-responses among surveyed institutions remained stable across time and across each type of institution. Further analysis on attrition is conducted in the following section.

Descriptive statistics for the overall, between, and within variation of forecasts, forecast errors and number of non-responses (i.e., attrition) are reported in Table 1. As shown, the mean exchange rate for 1 -month ahead forecasts $(\$ 2,140 \mathrm{COP} / \mathrm{USD})$ as well as the between and within variation (\$267 and \$274, respectively) are much lower than for the 1-year ahead forecasts (with a mean of \$2,255 COP/USD and between and within variation of $\$ 318$ and $\$ 329$, respectively). The attrition dummy

\footnotetext{
6 See Jongen et al. (2008) for a more in-depth literature review.

7 Frankel and Froot (1987), p. 134.

${ }^{8}$ Our sample period coincides with an inflation-targeting regime adopted by the Central Bank of Colombia in 1999 after the strongest crisis of its history. Prior to this date, pre-announced exchange rate bands were established, dating back to 1994. Access to aggregate data can be obtained in the central bank's website: http://www.banrep.gov.co.
} 


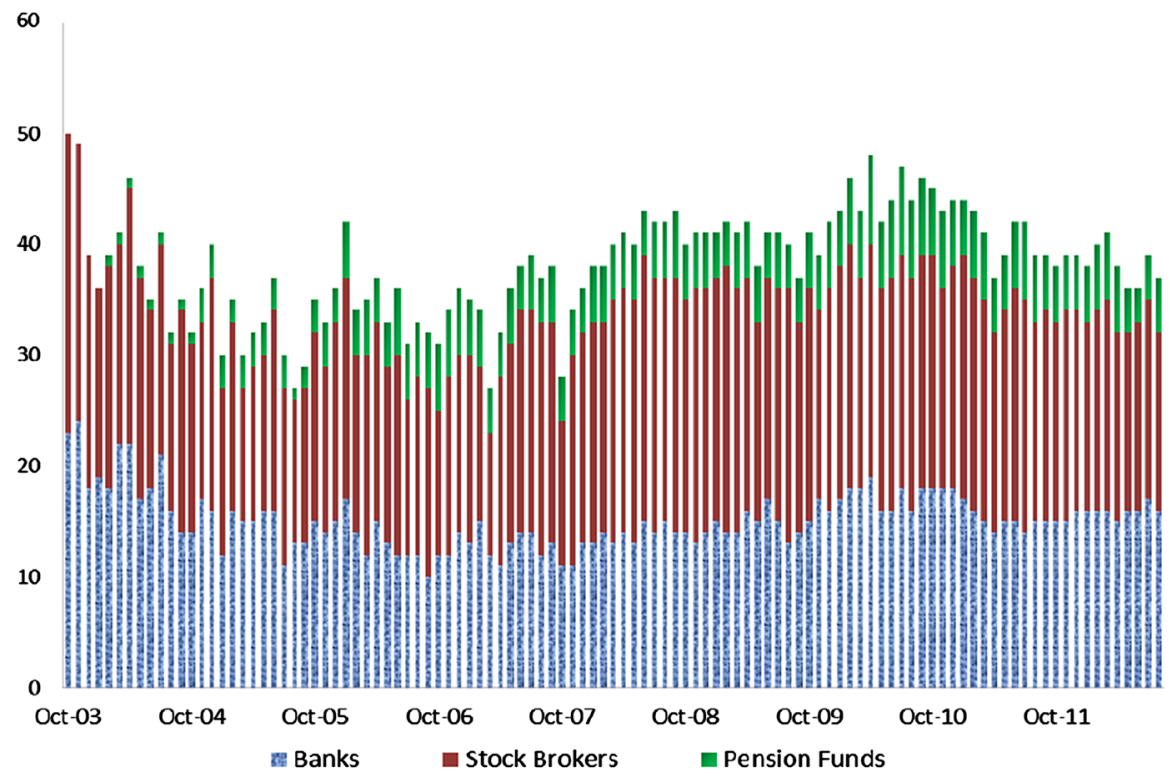

(a) Responses

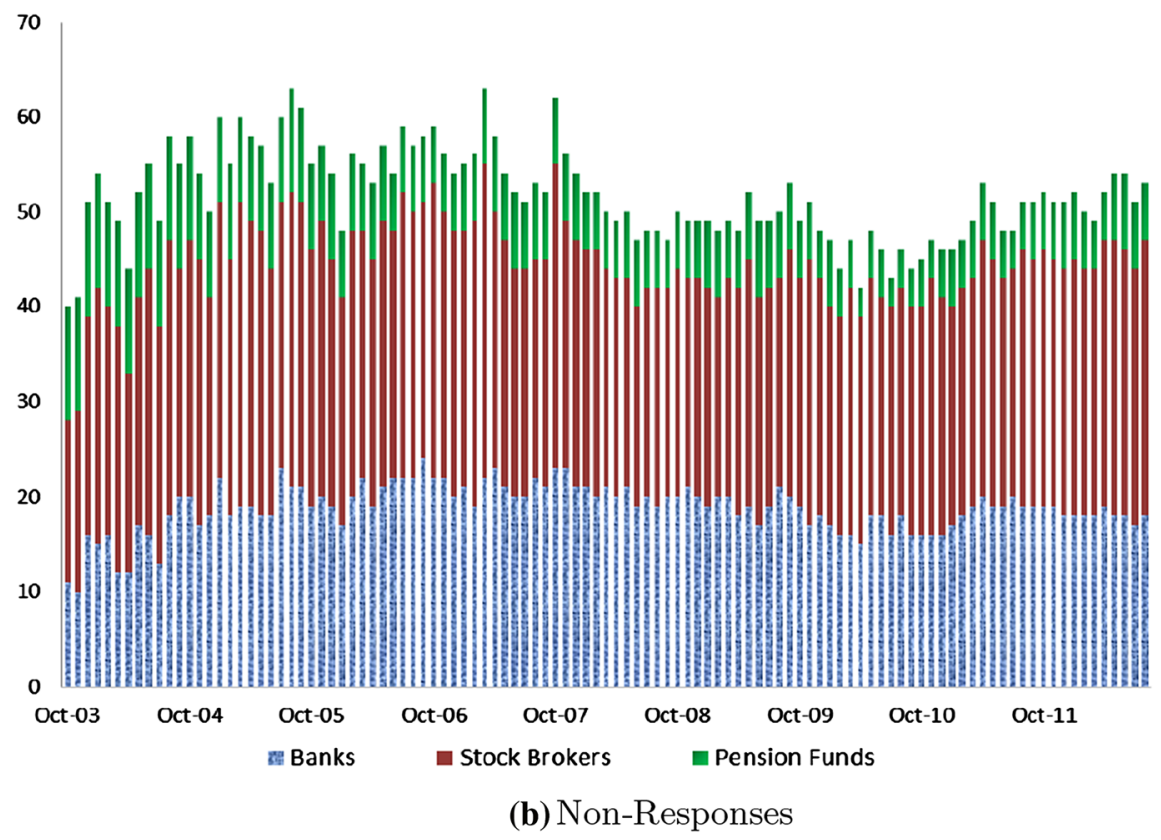

Fig. 1 Patterns of response and non-response 
Table 1 Overall, between, and within variation of selected variables

\begin{tabular}{lllllll}
\hline Variable & & Mean & St. dev & Min & Max & Observations \\
\hline 1-Month forecasts & Overall & 2140 & 319 & 1600 & 2982 & $N=4100$ \\
& Between & & 267 & 1756 & 2878 & $n=90$ \\
& Within & & 274 & 1593 & 3047 & $T=45.6$ \\
1-Year forecasts & Overall & 2255 & 389 & 1150 & 3425 & $N=3478$ \\
& Between & & 318 & 1761 & 3063 & $n=90$ \\
& Within & & 329 & 1144 & 3398 & $T=38.6$ \\
Attrition dummy & Overall & 0.57 & 0.49 & 0 & 1 & $N=9630$ \\
& Between & & 0.30 & 0.02 & 0.98 & $n=90$ \\
1-Month forecast errors & Within & & 0.39 & -0.41 & 1.56 & $T=107$ \\
& Overall & $-0.27 \%$ & $3.71 \%$ & $-17.1 \%$ & $16.8 \%$ & $N=4063$ \\
& Between & & $0.86 \%$ & $-3.05 \%$ & $1.64 \%$ & $n=90$ \\
& Within & & $3.67 \%$ & $-16.1 \%$ & $17.4 \%$ & $T=45.1$ \\
1-Year forecast errors & Overall & $9.06 \%$ & $12.6 \%$ & $-79.9 \%$ & $42.3 \%$ & $N=3090$ \\
& Between & & $6.27 \%$ & $-15.4 \%$ & $25.3 \%$ & $n=89$ \\
& Within & & $12.0 \%$ & $-80.4 \%$ & $41.1 \%$ & $T=34.7$ \\
\hline
\end{tabular}

Source: authors' calculations

shows an overall mean of non-responses of $57 \%$, with a similar variation across time and across financial institutions (30\% and $39 \%$, respectively). Finally, 1-year ahead forecast errors are large (overall mean of $9.06 \%$ ) compared to the 1-month ahead forecast errors (overall mean of $-0.27 \%$ ).

\subsection{Non-response incidence and potential attrition bias}

Sample attrition can lead to biased estimates when conducting causal inference, especially when observations are not missing at random (RAM). However, when non-responses are assumed to be MAR, the attrition bias disappears albeit with an effective reduction in sample size.

We follow the framework presented by Fitzgerald et al. (1998) and Cheng and Trivedi (2015) to test for attrition bias. ${ }^{9}$ Specifically, we investigate whether variables that affect attrition are also correlated with outcome variables of interest such as the 1-month and 1-year ahead forecasts. Formally, let the attrition function, $A_{i t}$, be an indicator function that takes the value of unity whenever a financial institution does not respond to the survey in period $t$, provided that it responded to the survey in period $t-1$ :

$$
A_{i t} \equiv\left[A_{i t}^{*}>0 \mid x_{i t}, A_{i t-1}\right]= \begin{cases}1 & \text { if } \mathrm{A}_{\mathrm{it}}^{*}>0 \\ 0 & \text { if } \mathrm{A}_{\mathrm{it}}^{*} \leq 0\end{cases}
$$

\footnotetext{
9 Additional tests such as the BGLW test, found in Becketti et al. (1985), have a similar structure but assume that attritioners exit the survey "once and for all". This assumption does not apply to our case since, as shown in Table 2, respondents exit and enter the survey multiple times.
} 
Table 2 Patterns of nonresponse

\begin{tabular}{lc}
\hline Non-responses (\% of time) & Number of institutions \\
\hline $0-10$ & 8 \\
$10-20$ & 8 \\
$20-30$ & 3 \\
$30-40$ & 8 \\
$40-50$ & 9 \\
$50-60$ & 5 \\
$60-70$ & 11 \\
$70-80$ & 10 \\
$80-90$ & 13 \\
$90-100$ & 15 \\
\hline
\end{tabular}

Source: authors' calculations.

Results are based on 90 financial institutions surveyed during Oct 2003-Aug 2012

where $x_{i t}$ is a set of control variables observed in period $t$. The latent attrition function $\left(A_{i t}^{*}\right)$ and outcome equation $\left(y_{i t}^{*}\right)$, can be expressed, in a linear setting as:

$$
\begin{gathered}
A_{i t}^{*}=x_{i t}^{\prime} \gamma+\varepsilon_{1 i t} \\
y_{i t}^{*}=z_{1 i t}^{\prime} \beta_{1}+z_{2 i t}^{\prime} \beta_{2}+\alpha_{i}+\varepsilon_{2 i t},
\end{gathered}
$$

where $z_{1 i t}$ and $z_{2 i t}$ consist of time-varying and time-invariant covariates in the outcome equation. The observed outcome variable is then exemplified as:

$$
y_{i t}= \begin{cases}y_{i t}^{*} & \text { if } \mathrm{A}_{\mathrm{it}}^{*}>0 \\ - & \text { if } \mathrm{A}_{\mathrm{it}}^{*} \leq 0 .\end{cases}
$$

It follows that if residuals of Eqs. (2) and (3) are uncorrelated, then the attrition function and outcome variable are conditionally independent. In other words, the pair $\left(A_{i t}^{*}, y_{i t}^{*}\right)$ will be uncorrelated conditional on $x_{i t}, z_{1 i t}$, and $\alpha_{i}$. This framework fits well under the sample selection (Heckman correction) specification introduced by Heckman (1979).

Consequently, to test for attrition bias we first estimate a probit regression model (Eq. (2)), and test whether institution-specific variables such as past expected depreciation (surveyed answers from the previous month) or the financial type (bank, stockbroker or pension fund) had a significant effect on attrition. We also consider common variables (across entities) such as past exchange rate depreciation, episodes of capital controls, the forward discount, and the emerging market bond index (EMBI). ${ }^{10}$ Finally, we include the central bank's policy rate, board meetings, and exchange rate equilibrium forecasts.

Results are reported in Table 3 and suggest no evidence of attrition bias (i.e., no variable has a significant impact on attrition). In addition, the low value of the

\footnotetext{
${ }^{10}$ Capital controls on inflows were enacted between May 7, 2007 and October 8, 2008 and consisted of compulsory unremunerated reserve requirements. Namely, market participants were required to deposit $40 \%$ of inflows at the central bank during a period of 6 months without interest payments [see Echavarría et al. (2013)].
} 
Table 3 Attrition probit regression Source: authors' calculations

\begin{tabular}{lr}
\hline Variable & \\
\hline Past expected depreciation $E_{t}\left[\Delta S_{i, t-k}\right], k=1$ month & $-0.61(2.228)$ \\
Past expected depreciation $E_{t}\left[\Delta S_{i, t-k}\right], k=1$ year & $-0.14(0.930)$ \\
Financial type: banks, stock brokers, pension funds & $0.04(0.085)$ \\
Episode of capital controls $\left(D_{2007-2008}\right)$ & $-0.05(0.248)$ \\
Central bank's policy rate & $0.015(0.049)$ \\
Board meeting dates & $-0.06(0.111)$ \\
Forward discount $\left(F_{t}^{t+k}-S_{t}\right)$ & $-4.81(6.136)$ \\
Exchange rate equilibrium forecast & $0.41(1.457)$ \\
Emerging market bond index (Embi) & $-0.00(0.001)$
\end{tabular}

Dependent variable is the attrition function indicator (with a value of unity for missing values). Values correspond to Probit coefficients, not marginal effects. Pseudo $\mathrm{R}^{2}=0.0023$. Total number of observations: 755. Constant not reported

$* * *, * *, *$ correspond to significance levels of 1,5 and $10 \%$, respectively

Table 4 Accuracy of 1-month and 1-year forecasts

\begin{tabular}{|c|c|c|c|c|c|}
\hline Institution & Median & $\begin{array}{l}\text { Direction } \Delta S_{i, t+k} \\
k=1 \text { month }(\%)\end{array}$ & $\begin{array}{l}+/-50 \text { pesos } \\
k=1 \text { month }(\%)\end{array}$ & $\begin{array}{l}\text { Direction } \\
\Delta S_{i, t+k} \\
k=1 \text { year }(\%)\end{array}$ & $\begin{array}{l}+/-50 \text { pesos } \\
k=1 \text { year }(\%)\end{array}$ \\
\hline $\begin{array}{l}\text { Commercial } \\
\text { banks }\end{array}$ & 15 & 66 & 64 & 35 & 9 \\
\hline Stock brokers & 19 & 65 & 61 & 43 & 15 \\
\hline Pension funds & 5 & 65 & 66 & 49 & 20 \\
\hline
\end{tabular}

Source: authors' calculations

regression's overall fit (Pseudo $R^{2}$ of $0.23 \%$ ) suggests an absence of systematic responses of these variables on non-responses.

Finally, we estimate the attrition hazard (i.e., inverse mills ratio), defined as the conditional mean of the outcome equation's residual; that is, we estimate $E\left[\varepsilon_{2, i t} \mid\right.$ $\left.\varepsilon_{1, i t}\right]=\sigma_{12} \lambda_{i t}\left(x_{i t}^{\prime} \gamma\right)$ and use it as covariate for all panel regressions presented in Tables $4-5 .{ }^{11}$ In all cases, $\lambda_{i t}$ is not statistically significant, which provides further support of MAR observations within non-responses.

\section{Forecasts, forwards and the risk premium}

\subsection{How accurate are agents' forecasts?}

It appears as an empirical regularity in the literature that the expected exchange rate does not equal the observed future rate, often missing the direction of change. For

\footnotetext{
11 Note that $\sigma_{12}$ corresponds to the covariance between $\epsilon_{1 i t}$ and $\epsilon_{2 i t}$. In addition, $\lambda(\cdot)=\frac{\phi(\cdot)}{\Phi(\cdot)}$, where $\phi$ and $\Phi$ denote the $p d f$ and $c d f$ of a standard normal distribution, respectively.
} 
Table 5 Individual components of the 1-month forward discount (Eq. 3)

\begin{tabular}{lcllll}
\hline Year & $\begin{array}{l}\text { Forward } \\
\text { discount } \\
F_{t}^{t+k}-S_{t}\end{array}$ & $\begin{array}{l}\text { Future } \\
\text { depreciation }\end{array}$ & $\begin{array}{l}\text { Forecast error } \\
E_{t+k}\left[S_{i, t+k}\right]-S_{t+k}\end{array}$ & $\begin{array}{l}\text { Risk } \\
\text { premium } \\
r p_{t}\end{array}$ & $\begin{array}{l}\text { Expected } \\
\text { depreciation } \\
E_{t}\left[\Delta S_{i, t+k}\right]\end{array}$ \\
\hline 2003 (Oct-Dec) & 0.2 & -1.3 & 0.7 & 0.8 & -0.6 \\
2004 & 0.4 & -1.2 & 1.2 & 0.4 & 0.0 \\
2005 & 0.0 & -0.4 & 0.4 & 0.0 & 0.0 \\
2006 & -0.3 & -0.2 & -0.3 & 0.2 & -0.5 \\
2007 & 0.1 & -0.9 & 0.5 & 0.5 & -0.4 \\
2008 & 0.1 & 0.9 & -2.0 & 1.2 & -1.1 \\
2009 & -0.2 & -0.8 & -0.6 & 1.2 & -1.4 \\
2010 & -0.4 & -0.5 & -0.2 & 0.4 & -0.8 \\
2011 & -0.1 & 0.1 & -0.8 & 0.6 & -0.7 \\
2012 (Jan-Aug) & -0.1 & -1.2 & 0.2 & 0.8 & -0.9 \\
Average & 0.0 & -0.5 & -0.1 & 0.6 & -0.6 \\
\hline
\end{tabular}

Source: Central Bank Data and author's calculations (mean values)

example, Wakita (1989) and Ito (1990) find industry-specific bias in expectations. In addition, Mussa (1979) and Frankel and Froot (1987) find constant underpredictions of exchange rate forecasts. Lewis (1995) finds evidence of systematic forecast errors.

Figure 2 presents the 1-month (short run) and 1-year ahead (long run) average expected exchange rate during 2003-2012. As observed, episodes of exchange rate appreciation were generally followed by expectations of further appreciation in the short run, and by expectations of depreciation (reversals) in the long run. This twist in expectations partially explains the stabilizing nature of expectations that we find in Sect. 4. It also explains why many Colombian exporters were reluctant to hedge their operations in the forward exchange market.

This pattern is similar to the one found in Takagi (1991), for the yen-dollar exchange rate during 1985-1986. However, Fig. 2 shows that circumstances changed in 2011 and 2012 when the financial sector expected that the 1-year ahead exchange rate would remain constant or even appreciate. Figure 2 also exhibits some degree of short-term under-prediction for the 1-month ahead exchange rate, in the sense that expected appreciations were lesser in magnitude than observed appreciations (and vice versa for depreciations). Finally, the figure suggests that forecasts followed a similar pattern during the period in which Colombia enacted capital controls (May 2007-October 2008).

Expectations considered over the sample period behaved poorly in terms of accuracy. Figure 3 presents forecast errors for 1-month and 1-year ahead expectations, measured as the difference between the expected and observed future rate. As can be observed, 1-month forecast errors oscillated between negative and positive values, while the 1 -year forecast errors were, for the most part, positive. ${ }^{12}$

\footnotetext{
12 Expectations differed from the observed 1-month and 1-year ahead rate in up to 206 pesos/dollar (September 2007) and in up to 615 pesos/dollar (June 2007), respectively.
} 


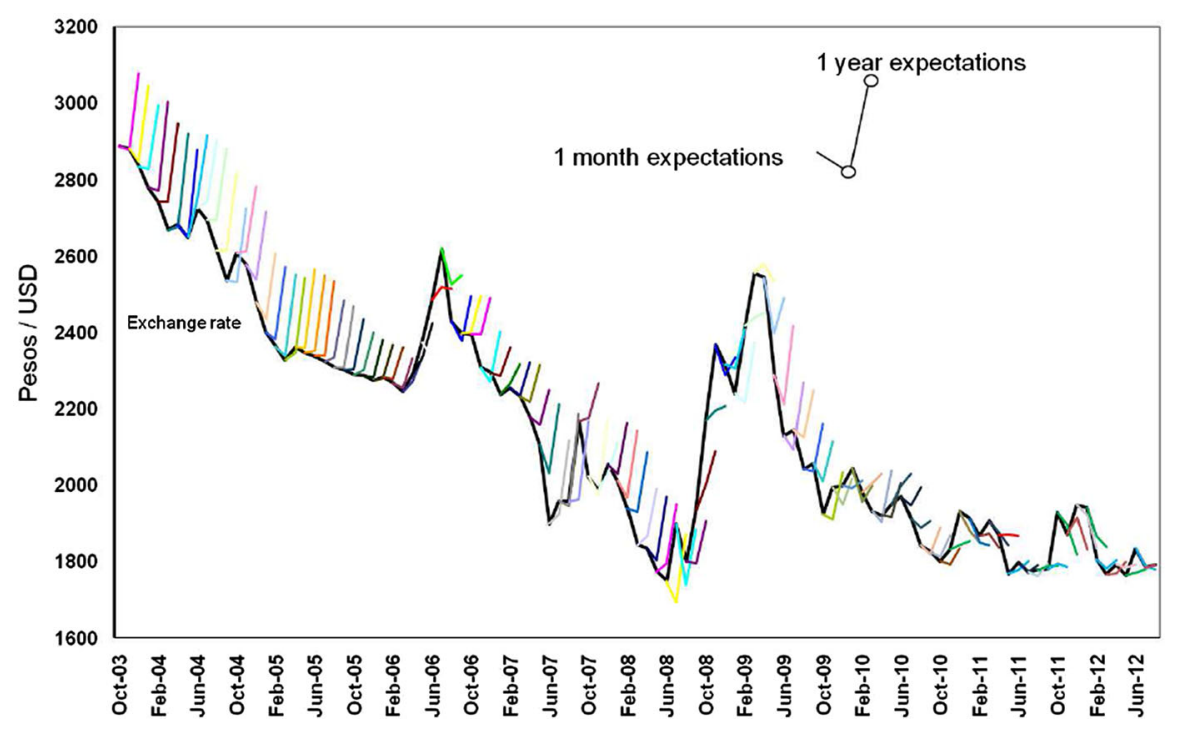

Fig. 2 Twist in Exchange Rate Expectations

The fact that yearly forecast errors were generally positive indicates, once again, a systematic bias towards expected depreciations. Finally, the figure shows that expectations behaved similarly across the different types of financial institutions.

Figure 4 shows the percentage of establishments that correctly predicted the exchange rate direction (i.e., a positive or negative variation). Again, there are marked differences between short- and long-term expectations. Financial institutions were able to correctly predict the direction of the exchange rate in $66 \%$ of cases for the 1-month horizon, but only in $40 \%$ of cases for the 1-year horizon (i.e., a fair coin would have outperformed the 1-year forecasts, invoking any law of large numbers). Levels of accuracy were particularly low in 2004 and high during episodes of steady appreciation (Jan 2005-Apr 2006, Nov 2007-Jun 2008). Similarly, Fig. 5 depicts forecast errors larger than $\$ 100$ Pesos $( \pm 50$ pesos / dollar) and shows that in many months, not a single entity was able to predict the 1-year ahead rate within that range.

The information contained in Figs. 4 and 5 is further sub-categorized in Table 6, by type of financial institution. As noted, 1-month ahead forecasts (columns 3 and 4) are similar across banks, stockbrokers and pension funds. This is not the case for the 1-year ahead forecasts (columns 5 and 6), where pension funds show a better forecasting accuracy.

\subsection{The forward discount and the risk premium}

Forward exchange rates have been widely used in the literature, not only to test for the covered interest rate parity, but also to test for the effectiveness of sterilized foreign exchange intervention or the existence (or absence) of a risk premium. For 


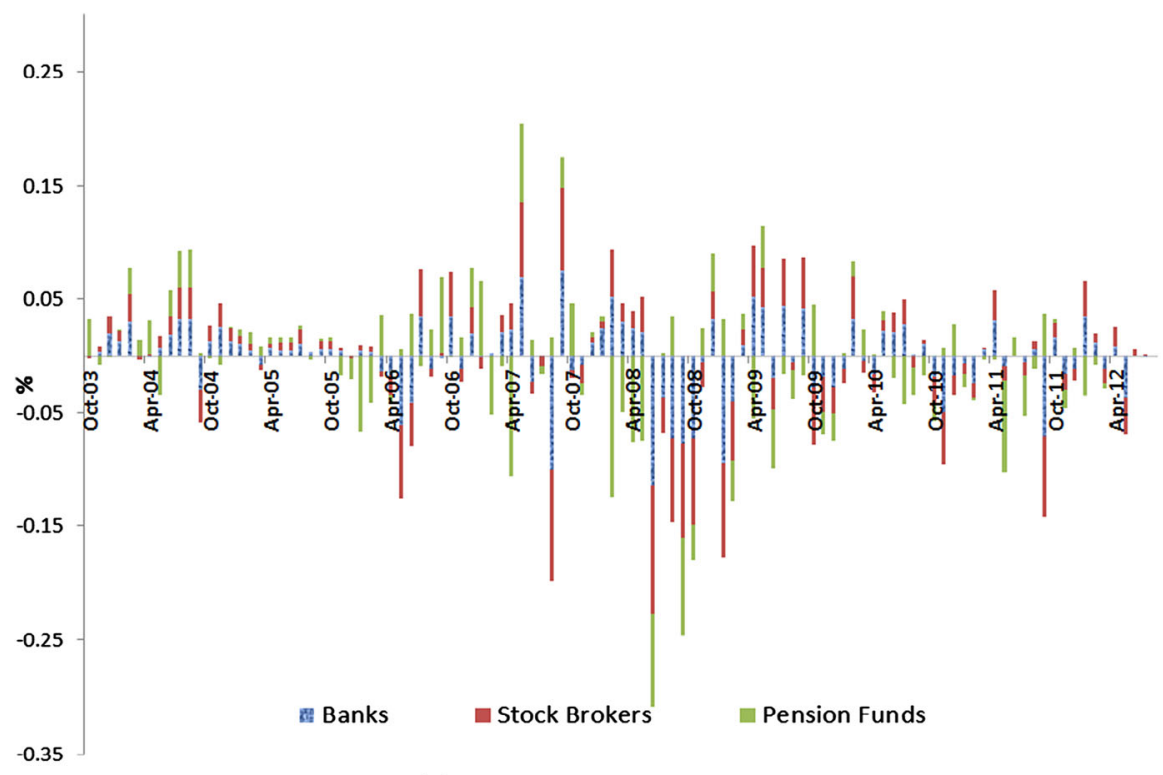

(a) 1-month Forecast Errors

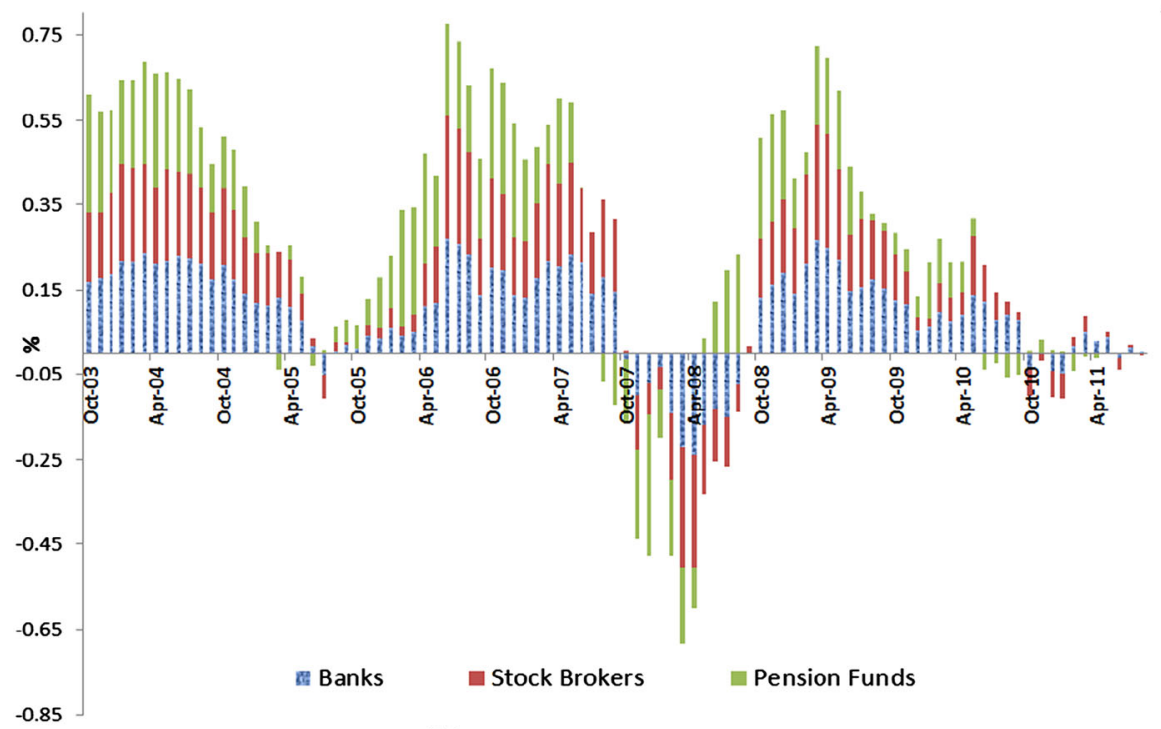

(b) 1-year Forecast Errors

Fig. 3 Forecast errors

the case of Colombia, Echavarría et al. (2008) show that the covered interest rate parity condition holds (on average) for all horizons considered, a result that is consistent with most of the international literature. 


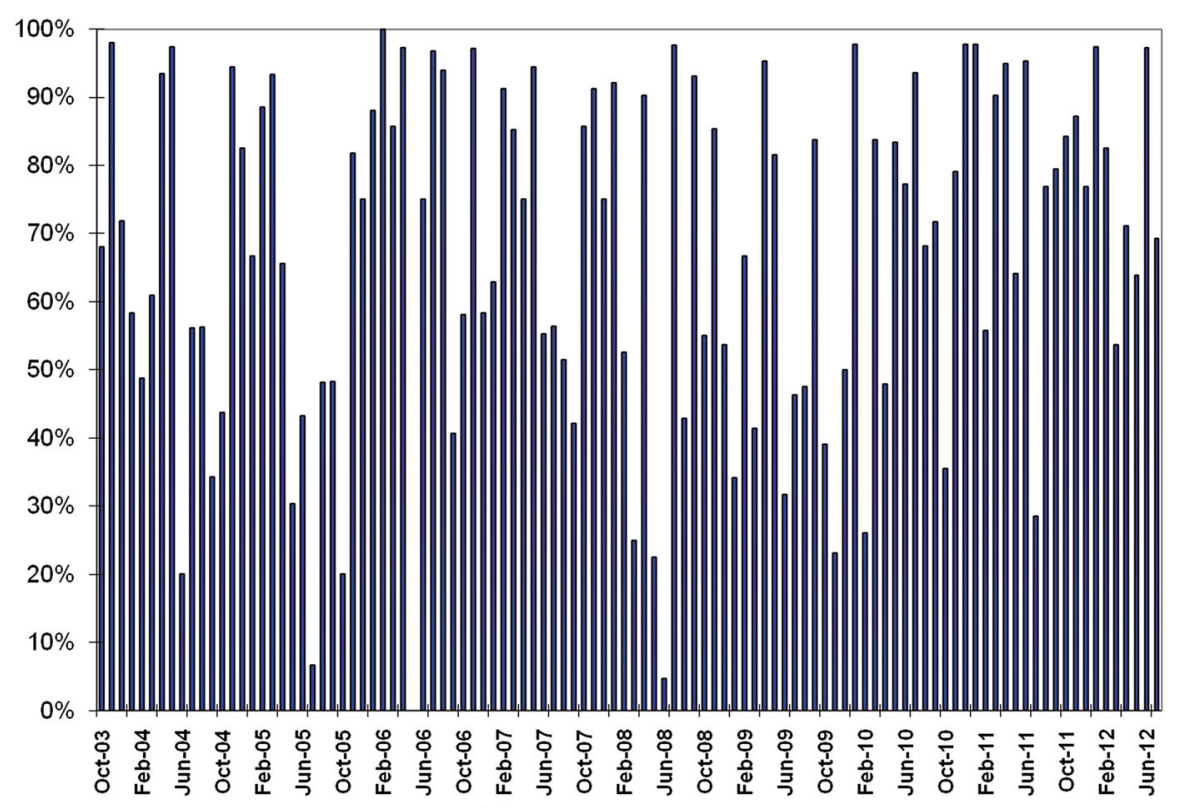

(a) 1-month Forecasts

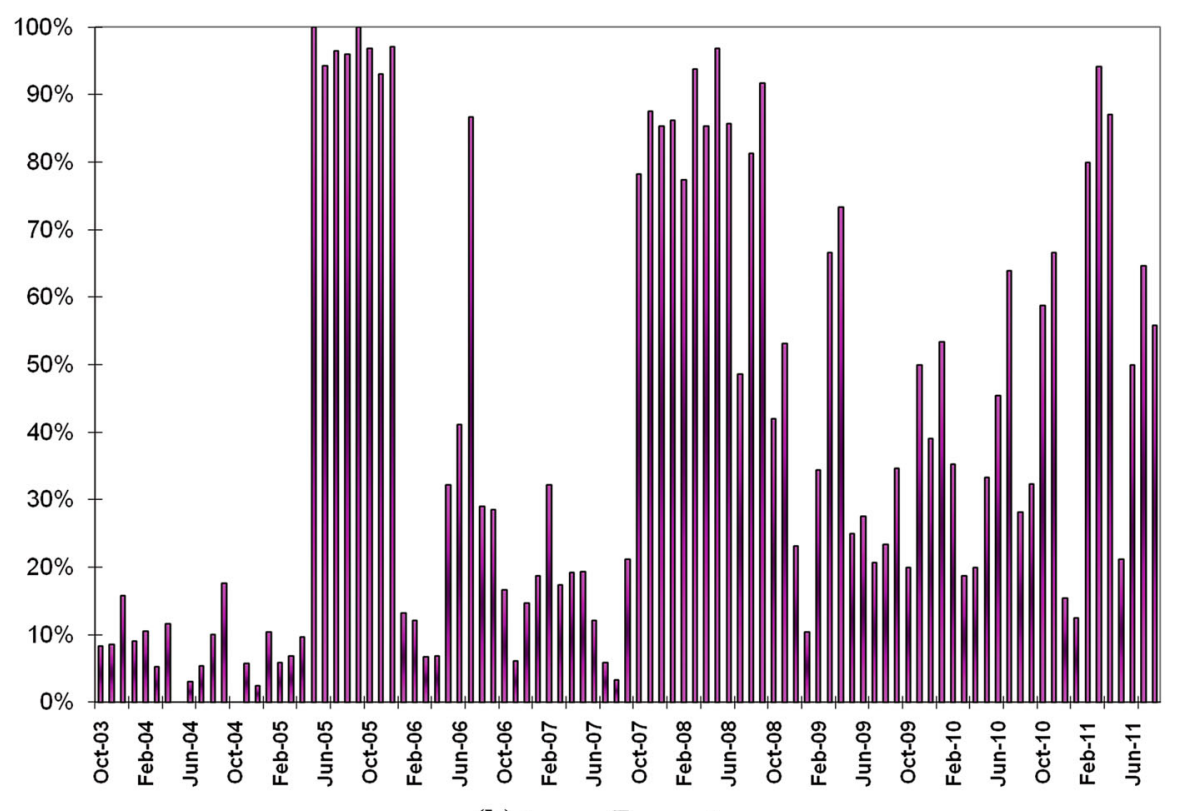

(b) 1-year Forecasts

Fig. 4 Percentage of institutions with correct exchange rate change direction 


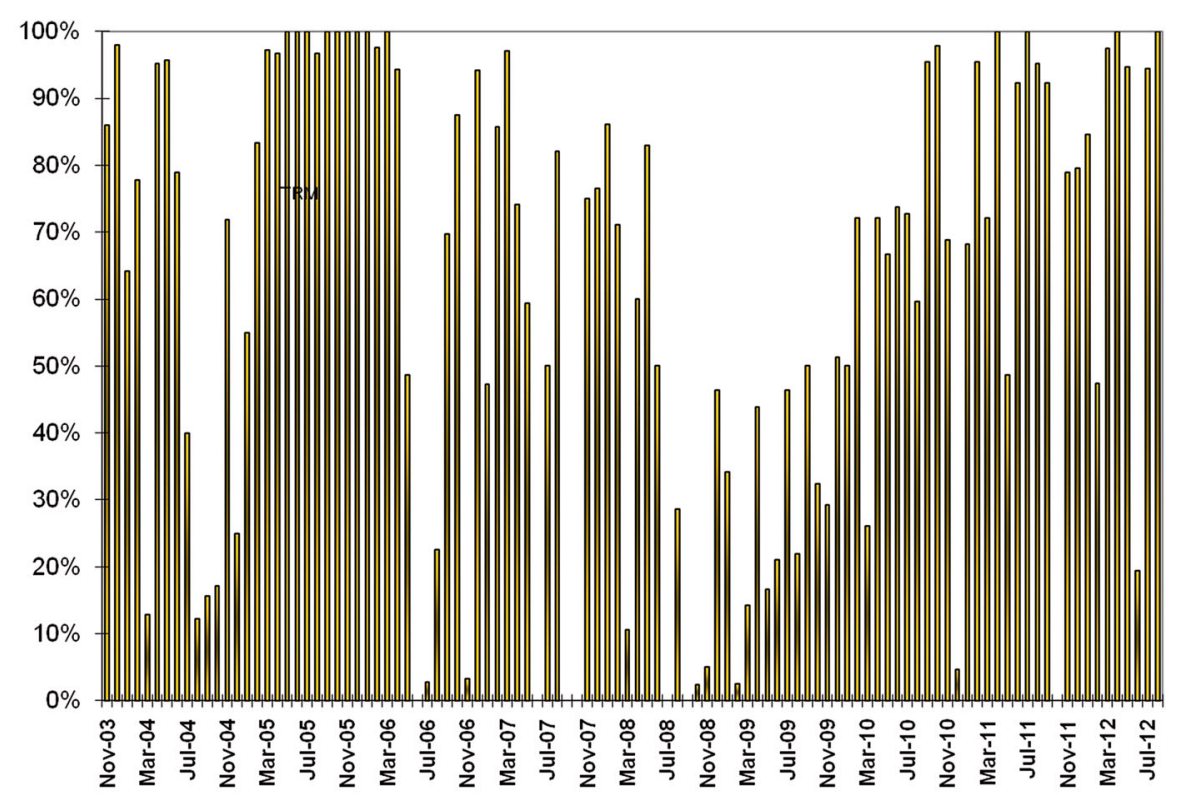

(a) 1-month Forecasts

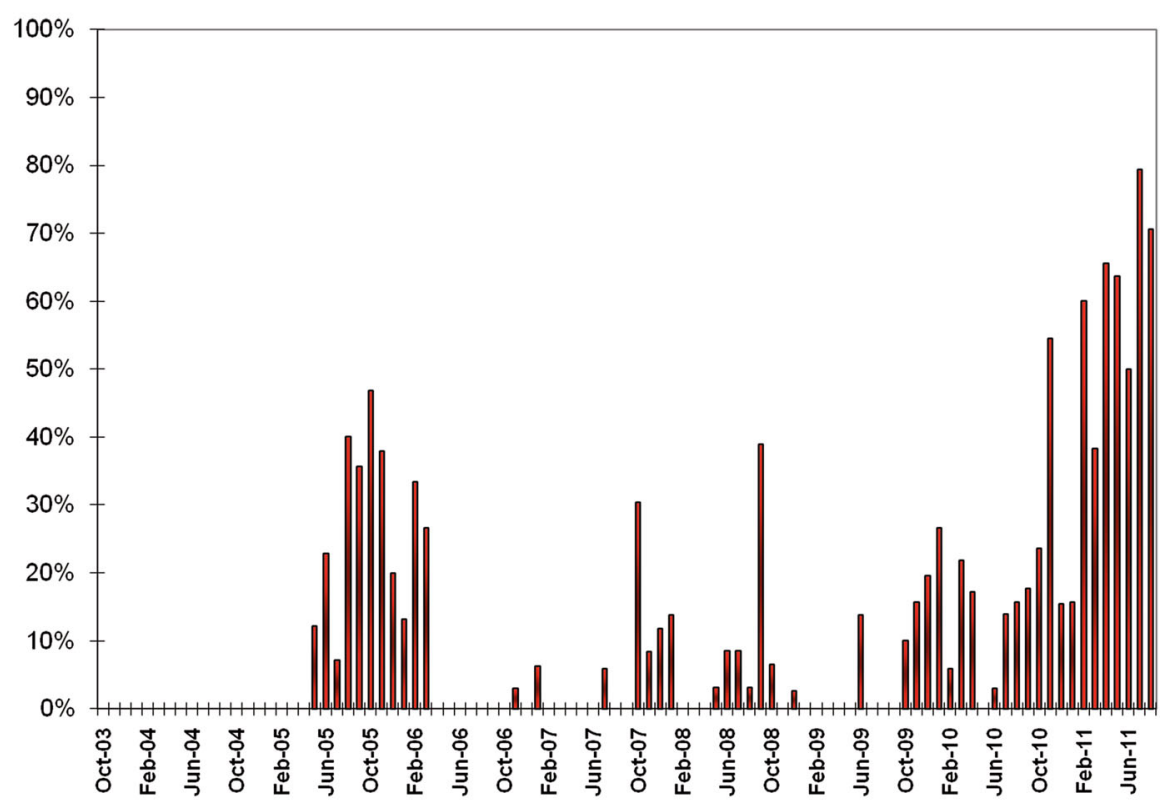

(b) 1-year Forecasts

Fig. $5 \%$ of Institutions falling within correct range of \pm 50 Pesos 
Table 6 Individual components of the 1-year forward discount (Eq. 3)

\begin{tabular}{lllclc}
\hline Year & $\begin{array}{l}\text { Forward } \\
\text { discount } \\
F_{t}^{t+k}-S_{t}\end{array}$ & $\begin{array}{l}\text { Future } \\
\text { depreciation }\end{array}$ & $\begin{array}{l}\text { Forecast error } \\
E_{t+k}\left[S_{i, t+k}\right]-S_{t+k}\end{array}$ & $\begin{array}{l}\text { Risk } \\
\text { premium } \\
r p_{t}\end{array}$ & $\begin{array}{l}\text { Expected } \\
\text { depreciation } \\
E_{t}\left[\Delta S_{i, t+k}\right]\end{array}$ \\
\hline 2003 (Oct-Dec) & 7.8 & -11.6 & 17.4 & 2.0 & 5.8 \\
2004 & 6.3 & -12.8 & 19.9 & -0.8 & 7.1 \\
2005 & 3.2 & 1.6 & 5.0 & -3.5 & 6.6 \\
2006 & 1.2 & -12.6 & 15.2 & -1.4 & 2.7 \\
2007 & 3.2 & -6.2 & 12.2 & -2.9 & 6.1 \\
2008 & 5.5 & 10.9 & -5.7 & 0.3 & 5.1 \\
2009 & 4.7 & -13.4 & 16.5 & 1.7 & 3.0 \\
2010 & 2.0 & -3.3 & 4.8 & 0.5 & 1.5 \\
2011 & 1.1 & 0.0 & -0.5 & 3.0 & -1.9 \\
2012 (Jan-Aug) & 3.2 & 0.0 & -0.7 & 3.9 & -0.7 \\
Average & 3.8 & -4.9 & 8.4 & 0.3 & 3.5 \\
\hline
\end{tabular}

Source: Central Bank Data and author's calculations (mean values)

Equations (5) and (6) show the covered and uncovered interest rate parity conditions, respectively, as presented in MacDonald and Taylor (1992), McCallum (1994), or Chinn (2007):

$$
\begin{gathered}
F_{t}^{t+k}-S_{t}=i_{t}-i_{t}^{*} \\
E_{t}\left[\Delta S_{t+k}\right]=i_{t}-i_{t}^{*}-r p_{t},
\end{gathered}
$$

where $F_{t}^{t+k}$ is the log forward exchange rate (to be exercised in period $t+k$ ), $S_{t}$ is the log spot exchange rate at time $t, E_{t}$ is the expected value operator, and $i_{t}$ and $i_{t}^{*}$ correspond to the domestic and foreign interest rates, respectively. By substituting Eq. (5) in 6, we obtain:

$$
\begin{aligned}
F_{t}^{t+k}-S_{t} & =E_{t}\left[\Delta S_{t+k}\right]+r p_{t} \\
& =\left(E_{t}\left[S_{t+k}\right]-S_{t+k}\right)+\Delta S_{t+k}+r p_{t},
\end{aligned}
$$

where the forward discount $\left(F_{t}^{t+k}-S_{t}\right)$ can be expressed in terms of the expected depreciation $E_{t}\left[\Delta S_{t+k}\right]$ and the risk premium $\left(r p_{t}\right)$. The second step of equation (7) also suggests that the forward discount can be expressed as the sum of the forecast errors $\left(E_{t}\left[S_{t+k}\right]-S_{t+k}\right)$, ex-post depreciations $\left(\Delta S_{t+k}\right)$, and the risk premium $\left(r p_{t}\right)$.

Most of the literature has found that the forward discount is not equal (on average) to the observed exchange rate change. For example, Fama (1984) and Hodrick and Srivastava (1984) assume that expectations are rational and give prominence to a risk premium in their explanation. The authors argue that the variance of the risk premium is greater than the variance of the expected depreciation. Similarly, Dominguez and Frankel (1993) show that, for imperfect 
substitutes, an increase in the amount of an asset results in either an increase in the expected return or an increase in the risk premium. ${ }^{13}$

Intuitively, the risk premium shown in Eq. (7) can be thought of as the difference between a risk-free investment (in this case hedged by the forward rate) and a risky investment subject to unexpected exchange rate changes. Thus, in the case of riskneutral agents, the market forward rate would equal the return's expected value, eliminating the risk premium. If agents are risk averse, the risk premium would take on positive values to compensate for the increased uncertainty of the risky asset.

Figure 6 depicts both the forward and expected exchange rates and shows that the 1-month forward rate follows the expected rate closely (unlike the case for the 1 -year expected rate). The figure also shows that in periods of exchange rate appreciation, the 1-year forward rate is lower than the expected rate, suggesting the existence of a negative risk premium (and vice versa for depreciations).

Similarly, Tables 7 and 8 report the individual components of Eq. (7) for both 1-month and 1-year ahead forecasts. Table 7 shows that the difference between the forward discount and the observed exchange rate change is relatively small for 1-month forecasts (with an average value of $0.5 \%$ and a maximum of $1.6 \%$ in 2004). Alternatively, Table 8 shows that this difference is large for 1-year forecasts (with an average of $8.7 \%$ and a maximum value of $19.4 \%$ in 2003). It also shows that 1-year forecast errors are large (average of $8.4 \%$ and a maximum value of $19.9 \%$ in 2004).

\subsection{The risk premium and the rational expectations hypothesis}

The use of forward rates to predict future spot exchange rates is based on the EMH, which precludes high above-normal profits through arbitrage in the forward market. This in turn encompasses the following joint hypothesis: (1) that expectations are formed rationally, and (2) that market participants are risk neutral. In sum, the efficient market hypothesis can fail as a result of non-rational expectations, or the existence of a time-varying risk premium, or both [see Hodrick (1987) and Engel (1996)].

Frenkel (1976) was one of the pioneers to test for the unbiasedness of forward rates as predictors of future exchange rates (both variables measured in levels). However, the non-stationarity properties of these variables presented a potential spurious regression problem, which was later addressed by Garbers (1987), Crowder (1994), Baillie et al. (1996), and Maynard and Phillips (2001). ${ }^{14}$

The conventional methodology for testing the existence of a risk premium, as proposed by Fama (1984), is to use ex-post exchange rates as a proxy for exchange rate expectations. The critical disadvantage to this approach is that it assumes

\footnotetext{
13 Some of the earliest empirical findings that reject the unbiasedness of forward rates (as predictors of future spot exchange rates) include those of Levich (1979), Hansen and Hodrick (1980), Bilson (1980), Hsieh (1983), Hansen and Hodrick (1983), and Hodrick and Srivastava (1986).

14 Some authors, like Kaminsky and Peruga (1990) and Baillie et al. (1996), include an unobservable risk premium in their models to account for differences in statistical properties when regressing return spreads on exchange rate changes.
} 
3000

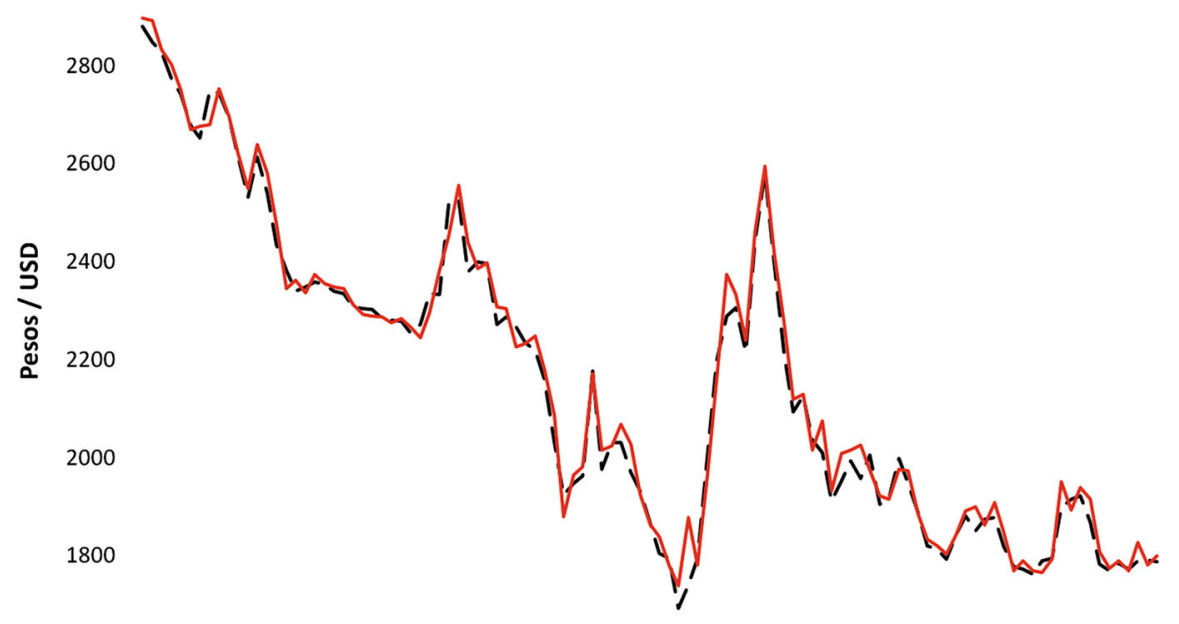

1600

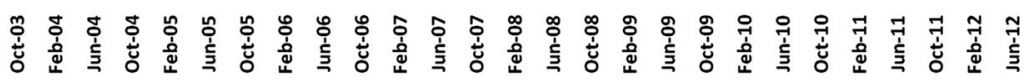
- Expected Rate — Forward Rate

(a) 1-month Horizon

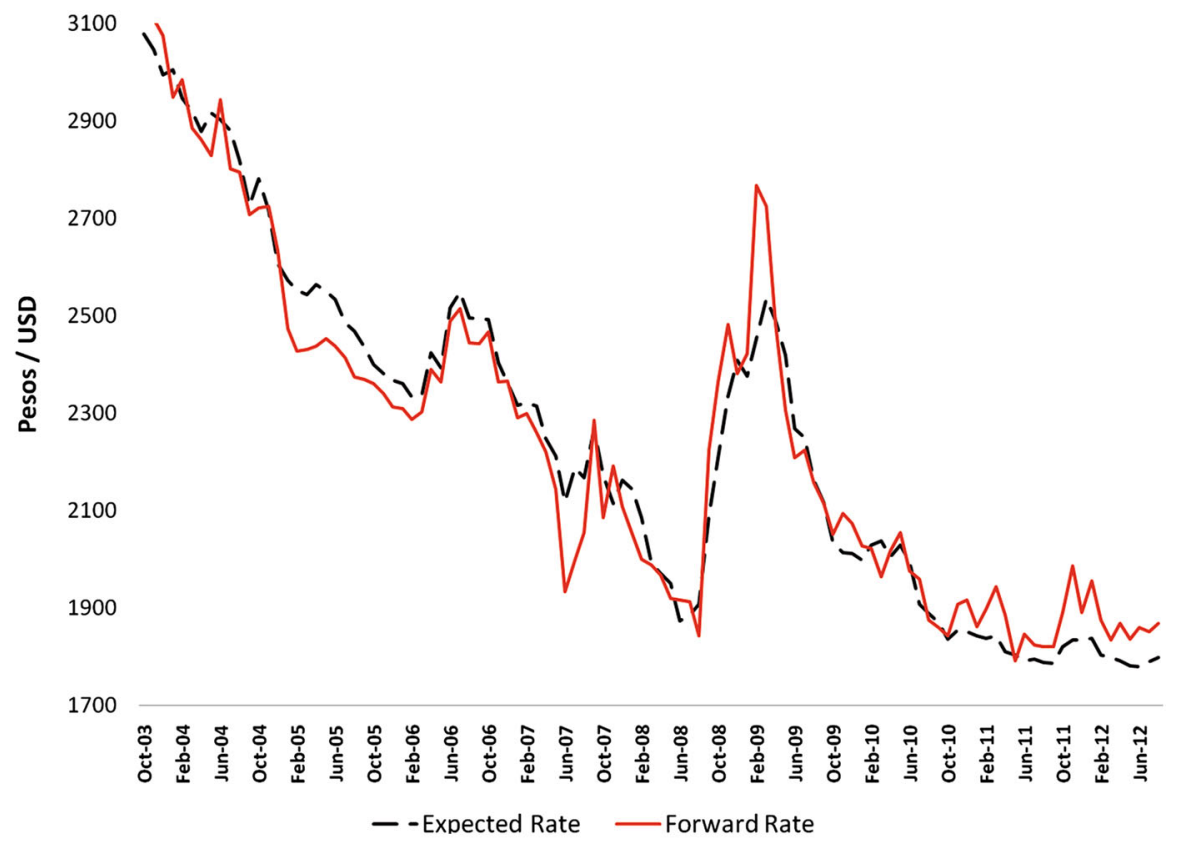

(b) 1-year Horizon

Fig. 6 Forward vs. expected exchange rates 
Table 7 Risk premium: $E_{t}\left[\Delta S_{i, t+k}\right]=\beta_{0}+\beta_{1}\left(F_{t}^{t+k}-S_{t}\right)+\beta_{2} \lambda\left(\frac{x_{i t}^{\prime} \beta}{\sigma}\right)+\sum_{j} \gamma_{j} D_{\text {year }}+\alpha_{i}+\epsilon_{i t}$

\begin{tabular}{llllll}
\hline Coefficient/test & \multicolumn{2}{l}{$k=1$ month } & & $k=1$ year \\
\cline { 2 - 3 } \cline { 5 - 6 } & First differences & Fixed effects & & First differences & Fixed effects \\
\hline$\beta_{0}$ & $0.00(0.003)$ & $-0.01 * * *(0.001)$ & & $-0.00(0.003)$ & $0.03 * * *(0.005)$ \\
$\beta_{1}$ & $0.95 * * *(0.047)$ & $1.07 * * *(0.041)$ & & $0.39 * * *(0.035)$ & $0.46^{* * * *}(0.034)$ \\
$\beta_{2}$ & $0.00(0.003)$ & $0.00(0.002)$ & & $0.00(0.005)$ & $0.00(0.005)$ \\
$t: \beta_{1}=1$ & $1.30(0.257)$ & $2.96^{*}(0.089)$ & & $294 * * *(0.000)$ & $251^{* * *}(0.000)$ \\
Wald $: \beta_{0}=0 \beta_{1}=1$ & $1.14(0.324)$ & $36.9 * * *(0.000)$ & & $150 * * *(0.000)$ & $126 * * *(0.000)$ \\
Observations & 3611 & 4100 & & 2869 & 3443 \\
\hline
\end{tabular}

Source: authors' calculations. $\beta_{2}$ corresponds to the inverse mills ratio, $\lambda(\cdot)$, estimated from the Attrition Probit Regression (see Table 3). All estimations were conducted with clustered standard errors, reported in parenthesis. $\mathrm{P}$ values are reported only for the t test and Wald test (last two rows). Coefficients for time dummies are not reported.The Hausman test, conducted for all regressions, rejects the null hypothesis in which the unobserved time-invariant component is uncorrelated with the model's covariates $* * *, * *, *$ correspond to significance levels of 1,5 and $10 \%$, respectively

Table 8 Unbiasedness: $E_{t}\left[\Delta S_{i, t+k}\right]=\beta_{0}+\beta_{1} \Delta S_{t+k}+\beta_{2} \lambda\left(\frac{x_{i t}^{\prime} \beta}{\sigma}\right)+\sum_{j} \gamma_{j} D_{\text {year }}+\alpha_{i}+\epsilon_{i t}$

\begin{tabular}{llllll}
\hline Coefficient/test & $k=1$ Month & & & $k=1$ Year \\
\cline { 2 - 3 } \cline { 5 - 6 } & First differences & Fixed effects & & First differences & Fixed effects \\
\hline$\beta_{0}$ & $0.00(0.001)$ & $-0.00^{* * *}(0.001)$ & & $-0.00(0.003)$ & $0.07 * * *(0.005)$ \\
$\beta_{1}$ & $0.30 * * *(0.011)$ & $0.27 * * *(0.011)$ & & $0.26 * * *(0.022)$ & $0.12 * * *(0.018)$ \\
$\beta_{2}$ & $0.00(0.003)$ & $0.00(0.002)$ & & $0.00(0.005)$ & $0.00(0.005)$ \\
$t: \beta_{1}=1$ & $3703 * * *(0.000)$ & $4750^{* * *}(0.000)$ & & $1118^{* * *}(0.000)$ & $2509 * * *(0.000)$ \\
Wald $: \beta_{0}=0 \beta_{1}=1$ & $1857 * * *(0.000)$ & $2786 * * *(0.000)$ & & $564 * * *(0.000)$ & $2053 * * *(0.000)$ \\
Observations & 3611 & 4100 & & 2869 & 3443
\end{tabular}

Source: authors' calculations. $\beta_{2}$ corresponds to the inverse mills ratio, $\lambda(\cdot)$, estimated from the attrition probit regression (see Table 3). All estimations were conducted with clustered standard errors, reported in parenthesis. $\mathrm{P}$ values are reported only for the t test and Wald test (last two rows). Coefficients for time dummies are not reported. The Hausman test, conducted for all regressions, rejects the null hypothesis in which the unobserved time-invariant component is uncorrelated with the model's covariates $* * *, * *, *$ correspond to significance levels of 1,5 and $10 \%$, respectively

rational expectations instead of testing them. Thus, it is impossible to determine whether evidence of a risk premium is in fact attributed to a time-varying risk or to the failure of rational expectations. Assuming that our survey data accurately represent agents' expectations, we can directly test for the presence of a risk premium without making any ad hoc assumptions on rationality. Hence, to statistically test if the forward rate is an unbiased predictor of the expected exchange rate, we estimate equation (8) as proposed by MacDonald and Torrance (1990), Frankel and Froot (1989) and Frankel and Froot (1990a):

$$
E_{t}\left[\Delta S_{i, t+k}\right]=\beta_{0}+\beta_{1}\left(F_{t}^{t+k}-S_{t}\right)+\beta_{2} \lambda\left(\frac{x_{i t}^{\prime} \beta}{\sigma}\right)+\sum_{j} \gamma_{j} D_{\text {year }}+\alpha_{i}+\epsilon_{i t},
$$


where the expected future exchange rate, $E_{t}\left[S_{i, t+k}\right]$, is obtained from the central bank's survey, and $F_{t}^{t+k}-S_{t}$ corresponds to the forward discount. In this panel setting, " $i$ " corresponds to cross-sectional dimension. A constant is also added to account for the convexity term arising from Jensen's inequality. ${ }^{15}$

Table 4 presents the estimated coefficients, a $t$ test for the null hypothesis $H_{0}: \beta_{1}=1$, and a Wald test for the joint hypothesis $\beta_{0}=0$ and $\beta_{1}=1$. Results are reported using both First Differences and Fixed Effects with clustered standard errors (reported in parenthesis). The Hausman test, conducted for all regressions, rejects the null hypothesis in which the unobserved time-invariant component $\left(\alpha_{i}\right)$ is uncorrelated with the model's covariates.

Results are similar for all specifications considered. The null $H_{0}: \beta_{1}=1$ and $H_{0}: \beta_{0}=0 \cap \beta_{1}=1$ are rejected for all horizons except for 1-month forecasts using first differences. These results are somewhat different to those found by Frankel and Froot (1989) who reject the null for 1-month forecasts, but do not reject the null for 3-month, 6-month and 1-year horizons. ${ }^{16}$

In addition to the presence of a risk premium, it is of interest to test for rational expectations so as to validate (or not) the use of ex-post exchange rates as proxies of exchange rate expectations. Recall that to determine if expectations are rational they must: (1) be unbiased predictors of the ex-post future exchange rate (unbiasedness), and (2) contain all useful information available at the time when they are formed (orthogonality). Although the first result alone would be sufficient to reject rational expectations, we also test for the orthogonally condition to shed additional light on whether expectations capture the impact of news and some selected fundamentals.

Table 9 presents estimations for the unbiasedness condition as proposed by Allen and Taylor (1990), Frankel and Froot (1990b) and MacDonald and Torrance (1990). Results show that the joint hypothesis $\beta_{0}=0 \cap \beta_{1}=1$ is rejected for all cases. We also estimate the effects of average forecasts on future exchange rate changes to avoid a potential endogeneity problem (i.e., when using ex-post values of the exchange rate as covariates). Table 5 shows that the null $H_{0}: \beta_{1}=1$ is also rejected for all horizons.

Regarding the orthogonality condition, if agents use all available information, then any covariate should be orthogonal to the forecast error. Dominguez (1986), MacDonald and Torrance (1990) and Benassy-Quere et al. (2003) find that rejection of the null hardly ever occurs at 1 -week and 2-week horizons. Rejection of the null is more frequent at the 1-month horizon, and becomes strongest when considering horizons larger than 3 months. At 1-year horizons, rejection becomes an empirical regularity.

We considered four key fundamentals to regress (individually) against agent's forecast errors, consisting of: meeting dates of the central bank's board of directors, changes in the announced policy rate, the forward discount, and past exchange rate changes. Results are reported in Table 10 and show that all variables had a significant impact over the 1-month forecast errors or the 1-year forecast errors. Consistently, the last row ( $F$ test) shows that all specifications reject the null that states that all coefficients are equal to zero.

\footnotetext{
${ }^{15}$ See MacDonald and Torrance (1990).

${ }^{16}$ Seemingly Unrelated Regressions (SUR) were also considered (not reported) to allow for crossequation contemporaneous correlations, yielding very similar results.
} 
Table 9 Unbiasedness (2): $\Delta S_{t+k}=\beta_{0}+\beta_{1} E_{t}\left[\Delta S_{i, t+k}\right]+\beta_{2} \lambda\left(\frac{x_{i t}^{\prime} \beta}{\sigma}\right)+\sum_{j} \gamma_{j} D_{\text {year }}+\epsilon_{t}$

\begin{tabular}{llllll}
\hline Coefficient/test & $k=1$ month & & & $k=1$ year \\
\cline { 2 - 3 } \cline { 5 - 6 } & First differences & Fixed effects & & First differences & Fixed effects \\
\hline$\beta_{0}$ & $0.01^{* * *}(0.001)$ & $-0.01^{* * *}(0.001)$ & & $-0.01^{* * *}(0.001)$ & $-0.14^{* * *}(0.004)$ \\
$\beta_{1}$ & $0.72 * * *(0.036)$ & $0.68^{* * *}(0.028)$ & & $0.24^{* * *}(0.040)$ & $0.32^{* * *}(0.058)$ \\
$\beta_{2}$ & $0.00(0.003)$ & $0.00(0.003)$ & & $0.00(0.005)$ & $0.00(0.006)$ \\
$t: \beta_{1}=1$ & $57.4^{* * *}(0.000)$ & $144^{* * *}(0.000)$ & & $363^{* * *}(0.000)$ & $134^{* * *}(0.000)$ \\
Wald $: \beta_{0}=0 \beta_{1}=1$ & $41.7^{* * *}(0.000)$ & $96.7^{* * *}(0.000)$ & & $205^{* * *}(0.000)$ & $2801^{* * * *}(0.000)$ \\
Observations & 3611 & 4100 & & 2869 & 3443 \\
\hline
\end{tabular}

Source: authors' calculations. $\beta_{2}$ corresponds to the inverse mills ratio, $\lambda(\cdot)$, estimated from the Attrition Probit Regression (see Table 3). All estimations were conducted with clustered standard errors, reported in parenthesis. $\mathrm{P}$ values are reported only for the $\mathrm{t}$ test and Wald test (last two rows). Coefficients for time dummies are not reported. The Hausman test, conducted for all regressions, rejects the null hypothesis in which the unobserved time-invariant component is uncorrelated with the model's covariates

***, **, * correspond to significance levels of 1,5 and $10 \%$, respectively

To our surprise, these results suggest that agents (on average) could have improved their forecasting accuracy by accounting for variation found in the forward discount, past exchange rate changes, policy meetings, or the policy rate. We note that the negative coefficient of past exchange rate changes for the 1-month horizon implies that in the short run, a depreciation leads to a systematic underprediction of the exchange rate (opposite to 1-year horizons).

\section{Stabilizing-destabilizing expectations}

Many models of exchange rate determination have made the simplifying assumption that expectations are static. In other words that expected depreciations are zero, or that the exchange rate follows a random walk. Advocates of this assumption, such as Meese and Rogoff (1983), show that a random walk performs as well as any other model for horizons of 1 month to 12 -months, for a series of exchange rates. Other supporters claim that floating exchange rates are highly unstable. For Nurkse (1944) (pp. 118):
"[Speculative] anticipations are apt to bring about their own realization. Anticipatory purchases of foreign exchange tend to produce or at any rate to hasten the anticipated fall in the exchange value of the national currency, and the actual fall may set up or strengthen expectations of a further fall ... Exchange rates under such circumstances are bound to become highly unstable, and the influence of psychological factors may at times be overwhelming"

Contrary to this strand of literature, Friedman (1953) advocacy for floating exchange rates was based on the stabilizing effect of expectations, that is, if current or past appreciations of domestic currency induce agents to expect future depreciations, then they will seek to sell domestic currency, and hence, mitigate much of the current appreciation. 
Table 10 Orthogonality condition: $E_{t}\left[S_{i, t+k}\right]-S_{t+k}=x_{i t}^{\prime} \beta+\sum_{j} \gamma_{j} D_{\text {year }}+\alpha_{i}+\epsilon_{i t}$

\begin{tabular}{|c|c|c|c|c|}
\hline \multirow[t]{2}{*}{ Coefficient/test } & \multicolumn{2}{|l|}{$k=1$ month } & \multicolumn{2}{|l|}{$k=1$ year } \\
\hline & First differences & Fixed effects & First differences & Fixed effects \\
\hline Board Meetings $s_{t}$ & $\begin{array}{c}-0.18^{* * * *} \\
(0.012)\end{array}$ & $\begin{array}{c}-0.07 * * * \\
(0.007)\end{array}$ & $0.15^{* * *}(0.034)$ & $-0.02(0.026)$ \\
\hline$\Delta$ Policy Rate $_{t}$ & $0.01 * * *(0.002)$ & $-0.01 * *(0.003)$ & $0.00(0.004)$ & $-0.02 * *(0.009)$ \\
\hline Forward Discount $t_{t}$ & $\begin{array}{c}-0.46^{* * *} \\
(0.051)\end{array}$ & $\begin{array}{c}-0.60 * * * \\
(0.041)\end{array}$ & $\begin{array}{r}-0.11 * * \\
(0.046)\end{array}$ & $\begin{array}{c}-0.39 * * * \\
(0.065)\end{array}$ \\
\hline $\begin{array}{l}\text { Exchange rate } \\
\text { Changes }_{t-1}\end{array}$ & $0.30 * * *(0.013)$ & $-0.06(0.013)$ & $0.13 * * *(0.033)$ & $0.37 * * *(0.048)$ \\
\hline Ftest : All $\beta s=0$ & $201 * * *(0.000)$ & $97.7 * * *(0.000)$ & $8.33 * * *(0.000)$ & $31.1 * * *(0.000)$ \\
\hline Observations & 3575 & 4063 & 2513 & 3055 \\
\hline
\end{tabular}

Source: authors' calculations. All estimations were conducted with clustered standard errors, reported in parenthesis. $P$ values are reported only for the $F$ test (last row). The Hausman test, conducted for all regressions, rejects the null hypothesis in which the unobserved time-invariant component is uncorrelated with the model's covariates

$* * *, * *, *$ correspond to significance levels of 1,5 and $10 \%$, respectively. Coefficients for time dummies are not reported

Following Frankel and Froot (1986), Takagi (1991) and Frankel and Rose (1994), we consider three main processes of expectation formation to compare the forecasting accuracy of each, as well as to shed some light on the stabilizing or destabilizing effect that they might have over the short- and long-term exchange rate. The discussion is based on the general form of equation (9):

$$
E_{t}\left[S_{t+k}\right]=\beta x_{t}+(1-\beta) S_{t},
$$

where $x_{t}$ again is comprised of variables from investors' information set. Expectations can thus be seen as the weighted average of the contemporaneous spot rate and some other variable at time $t$. In the literature, there are three main candidates for $x_{t}$ : past exchange rates, past expected exchange rates, and long-term equilibrium values of the exchange rate. They correspond to extrapolative, adaptive, and regressive expectations, respectively. By substituting these candidates in Eq. (9), we obtain Eqs. (10)-(12):

$$
\begin{gathered}
E_{t}\left[S_{t+k}\right]-S_{t}=-\beta_{e x}\left(S_{t}-S_{t-k}\right) \\
E_{t}\left[S_{t+k}\right]-S_{t}=-\beta_{a d}\left(S_{t}-E_{t-k}\left[S_{t}\right]\right) \\
E_{t}\left[S_{t+k}\right]-S_{t}=-\beta_{r e g}\left(S_{t}-\overline{S_{t}}\right),
\end{gathered}
$$

where as a proxy for the long-run equilibrium exchange rate $\left(\overline{S_{t}}\right)$, we use the mean of 7 (in house) models estimated by the Colombian Central Bank. ${ }^{17}$

\footnotetext{
17 Two of these models are based on the Purchasing Power Parity (PPP) condition, 2 are based on Vector Error Correction (VEC) methodologies and one model uses a Hodrick and Prescott filter.
} 
In sum, extrapolative expectations involve forecasting with past movements of the exchange rate (past variations are used to forecast the next period's variation). Under adaptive expectations, investors use current forecast errors to predict future exchange rates. Intuitively, if an agent expects the exchange rate to be higher than what is observed ex-post, then she will "correct" her new forecast by lessening her expectation of the next period's exchange rate change (expectations adapt to new changes given past mistakes). Finally, regressive expectations incorporate deviations of the exchange rate with respect to a long-run equilibrium value. This process assumes that the exchange rate "regresses" (at speed $\beta_{\text {reg }}$ ) towards a long-run value which can take the form of a constant, moving average, or purchasing power parity, among others [see Dornbusch (1976)].

The processes described in Eqs. (10-12) are stabilizing when agents believe that a large appreciation (depreciation) in the past will be followed by a smaller depreciation (appreciation) in the future. In other words, when the coefficients of $\beta_{\text {ex }}, \beta_{\text {ad }}$, and $\beta_{\text {reg }}$ are negative and less than unity (in absolute terms). The alternative hypothesis of static expectations (i.e., random walk) will occur when coefficients are zero. In the literature, Frankel and Froot (1990a) and Cavaglia et al. (1993) find positive values for $\beta_{\mathrm{ex}}, \beta_{\mathrm{ad}}$, and $\beta_{\text {reg }}$ when considering 1-month horizons, suggesting that short run expectations carry bandwagon or destabilizing effects. However, for horizons longer or equal than 3 months, the authors find stabilizing effects.

Table 11 presents results for Eqs. (10)-(12), estimated in a panel data setup. They show that expectations are stabilizing in all cases, with negative coefficients between $(-1,0)$, except for the case of regressive expectations at the 1-year horizon which shows a positive coefficient of less than unity. These results are partially related to the "Twist" in expectations presented in Fig. 2. They are also consistent with Villa (2011) who finds that expectations are stabilizing for nearly $85 \%$ of cases when considering extrapolative and adaptive expectations, and for more than $95 \%$ when considering regressive expectations.

\subsection{The random walk benchmark}

There is an ample literature on the unpredictability of exchange rates, in which studies often compare the accuracy of linear models with a benchmark random walk process. Most of these studies have generally followed the methodology presented in the seminal work of Meese and Rogoff (1983) but some earlier works include those of Nelson (1972), Christ (1975), Litterman (1979) and Fair (1979).

To date, most studies have failed to reject the null hypothesis that exchange rates are unpredictable. However, some exceptions are found in the literature. Evans and Lyons (2005), for example, use order flows as a successful determinant of future exchange rates. Cheung et al. (2005) find that models that incorporate productivity differentials outperform the random walk benchmark for some periods and currencies. Gourinchas and Rey (2005) are also able to outperform a random walk with a model that uses the trade balance and the valuation of net foreign assets. ${ }^{18}$

\footnotetext{
18 Studies that find predictable models for stock market returns are more abundant, and include Keim and Stambaugh (1986), Fama and French (1988) and Lo and MacKinlay (1987).
} 
Table 11 (De)-stabilizing expectations

\begin{tabular}{lll}
\hline Type of expectation & $k=1$ Month & $k=1$ Year \\
\hline Extrapolative $E_{t}\left[\Delta S_{i, t+k}\right]=\beta_{0}+\beta_{1} \Delta S_{t}+\epsilon_{i t}$ & $\beta_{1}=-0.03^{* *}(0.013)$ & $\beta_{1}=-0.13^{* * *}(0.015)$ \\
Adaptive $E_{t}\left[\Delta S_{i, t+k}\right]=\alpha_{0}+\alpha_{1}\left(S_{t}-E_{t-k}\left[S_{i t}\right]\right)+v_{i t}$ & $\alpha_{1}=-0.05^{* * *}(0.016)$ & $\alpha_{1}=-0.15^{* * *}(0.017)$ \\
Regressive $E_{t}\left[\Delta S_{i, t+k}\right]=\gamma_{0}+\gamma_{1}\left(S_{t}-\overline{S_{t}}\right)+\eta_{i t}$ & $\gamma_{1}=-0.05^{* * *}(0.005)$ & $\gamma_{1}=0.11^{* * *}(0.029)$ \\
\hline
\end{tabular}

Source: Authors' calculations. All estimations correspond to PANEL regressions with fixed effects and robust clustered standard errors, reported in parenthesis. Total number of observations: 4,100 for 1-month horizon and 3,478 for 1-year horizon

$* * *, * *, *$ correspond to significance levels of 1,5 and $10 \%$, respectively

Following the classic paper of Meese and Rogoff (1983) and a more recent paper like Rogoff (2009), in this section we set forth five competing models to assess how well they perform relative to a random walk. In the methodology that follows, we constructed Mean Squared Prediction Errors (MSPEs) for each model as well as for a driftless random walk, as shown in equation (13):

$$
M S P E=\frac{1}{N} \sum_{i=0}^{N-1}\left(E_{t}\left[\Delta \hat{S_{t+k+i}}\right]-E_{t}\left[\Delta S_{t+k+i}\right]\right)^{2},
$$

where $(\wedge)$ corresponds to the estimated value of the forecast error $\left(E\left[S_{t+k}\right]-S_{t}\right)$, and " $N$ " corresponds to the number of rolled-over forecast periods.

When conducting inference for nested models, it is important to control for an existing upward shift of the predicted sample errors. We account for this by following the methodology in the study by Clark and West (2006), that is, we construct MSPE-adjusted statistics in which, under the null hypothesis that models follow a martingale difference, the sample MSPE can be equal to that of the null. ${ }^{19}$ We thus proceed as follows: first we define our in-sample period to be from Oct 2003 to May 2005. We then estimate the corresponding models and make 1-period out of sample forecasts before rolling over the sample by one period. Finally, we construct MSPE-adjusted statistic for each model.

Results are presented in Table 12. The first column shows the different competing models (i.e., unrestricted models) that consist of extrapolative, adaptive, and regressive processes (described in the previous section), the forward discount $\left(F_{t}^{t+k}-S_{t}\right)$, and expected depreciations $\left(E_{t}\left[S_{t+k}-S_{t}\right]\right)$ from the central bank's survey. We considered expectations from all participants but also individually categorized commercial banks, stockbrokers and pension funds in rows: 7-9. Columns 2 and 3 show results for the $\left(M S P E_{r}-M S P E_{u}\right)$-adjusted statistic, using the methodology presented by Clark and West (2006). Hence, positive values indicate good predictors of the exchange rate, since they outperform a random walk (i.e., lower MSPEs than that of a random walk).

\footnotetext{
19 See the studies by Granger and Newbold (1977) and Ashley et al. (1980) for a list of methods that compare MSPEs. Other studies such as Meese and Rogoff (1988), Christiano (1989), West et al. (1993), and Diebold and Mariano (1995) offer more general forecast evaluation procedures.
} 
Table 12 Out-of-sample forecasts: competing models vs. random walk

\begin{tabular}{lll}
\hline Model & 1-Month $\left(\mathrm{MSPE}_{r}-\mathrm{MSPE}_{u}\right)$ & $1-\mathrm{Year}\left(\mathrm{MSPE}_{r}-\mathrm{MSPE}_{u}\right)$ \\
\hline Extrapolative & $-0.0006(0.001)$ & $0.18^{* * *}(0.042)$ \\
Adaptive & $-0.0004(0.001)$ & $0.20^{* * *}(0.045)$ \\
Regressive & $0.003^{* * *}(0.001)$ & $0.09^{* * *}(0.030)$ \\
Forward discount & $0.003^{* *}(0.002)$ & $0.03^{* *}(0.016)$ \\
Surveyed expectations & & \\
All participants & $0.009^{* * *}(0.002)$ & $0.01(0.013)$ \\
Commercial banks & $0.009^{* * *}(0.002)$ & $0.01(0.015)$ \\
Stockbrokers & $0.009^{* * *}(0.002)$ & $0.01(0.012)$ \\
Pension funds & $0.009^{* * *}(0.003)$ & $0.00(0.018)$ \\
\hline
\end{tabular}

Source: Authors' calculations. All estimations correspond to rolling regressions. $M S P E_{r}$ and $M E S P E_{u}$ correspond to "restricted" (Random walk) and "unrestricted" (competing strategies) models. Methodology follows that of Clark and West (2006). Standard errors are in parenthesis

$* * *, * * *$ correspond to significance levels of 1,5 and $10 \%$, respectively

Results for 1-month forecasts show that expectations stated in the survey outperform the three models of extrapolative, adaptive or regressive expectations, and also the forward discount. In fact, they outperform the random walk, with positive and significant numbers for $\left(\mathrm{MSPE}_{r}-\mathrm{MSPE}_{u}\right)$. But results are almost the opposite for 1-year forecasts in which the statistic $\left(\mathrm{MSPE}_{r}-\mathrm{MSPE}_{u}\right)$ is not significant for agent's forecasts (rows 6-9), but is significant for the case of extrapolative, adaptive, and regressive expectations, and even the forward discount. In sum, this exercise suggests that agents do exceptionally well in forecasting 1-month horizons but should reconsider their 1-year forecasts, that is, by following models presented in rows 1-4, agents can improve their forecasting accuracy.

We note that the employed loss function (MSPE) is explicitly symmetric. In other words, forecasts suffer the same loss independent of the sign of the error. To shed some light on this issue, we considered negative and positive forecast errors separately. Results are shown in Table 13 of Appendix A and show similar results, except for the case of regressive expectations (1-month forecasts are no longer significant) and the forward discount (1-year forecasts are no longer significant).

\section{Conclusion}

Exchange rate expectations play a key role in determining economic variables and, according to some authors like Woodford and Walsh (2005), "little else matter". However, there is wide disagreement on the behavior of exchange rate expectations, with various implications for economic policy.

Following the practice pioneered by Dominguez (1986), Frankel (1979), and Frankel and Froot (1987), in this paper we use the largest exchange rate survey in Colombia to test for the rational expectations hypothesis, the presence of a timevarying risk premium and the accuracy of exchange rate forecasts. Our main findings indicate that episodes of exchange rate appreciation preceded expectations 
of further appreciation in the short run, but were marked by depreciations in the long run. Additionally, we find that the forward discount differed from future exchange rate changes due to the rejection of the unbiasedness condition and to the presence of a time-varying risk premium.

Finally, we set forth five competing strategies to assess how well actual expectations performed relative to a random walk process. We find that 1-month expectations outperform models of extrapolative, adaptive or regressive expectations and even a random walk process (with lower mean squared prediction errors). But results are almost the opposite for 1-year forecasts, where expectations do not outperform a random walk. In this last case, traders and analysts answering the survey could have improved their forecasts by incorporating information from the forward discount, past exchange rate changes, policy meetings, or the policy rate.

Open Access This article is distributed under the terms of the Creative Commons Attribution 4.0 International License (http://creativecommons.org/licenses/by/4.0/), which permits unrestricted use, distribution, and reproduction in any medium, provided you give appropriate credit to the original author(s) and the source, provide a link to the Creative Commons license, and indicate if changes were made.

\section{Appendix A}

Table 13 Competing models vs. random walk for positive and negative forecast errors

\begin{tabular}{|c|c|c|c|c|}
\hline & \multicolumn{2}{|c|}{ Positive forecast errors } & \multicolumn{2}{|c|}{ Negative forecast errors } \\
\hline & 1-Month & 1-Year & 1-Month & 1-Year \\
\hline Extrapolative & $0.0003(0.001)$ & $0.19 * * *(0.035)$ & $-0.0003(0.001)$ & $0.21 * * *(0.046)$ \\
\hline Adaptive & $0.0002(0.001)$ & $0.17 * * *(0.033)$ & $-0.0002(0.001)$ & $0.31 * * *(0.051)$ \\
\hline Regressive & $0.0001(0.001)$ & $0.11 * * *(0.032)$ & $0.0009(0.001)$ & $0.06^{* * *}(0.022)$ \\
\hline Forward discount & $0.008 * * *(0.002)$ & $0.01(0.015)$ & $-0.001(0.001)$ & $-0.005(0.012)$ \\
\hline \multicolumn{5}{|c|}{ Surveyed expectations } \\
\hline All Participants & $0.001 * * *(0.000)$ & $-0.06(0.087)$ & $0.006 * * *(0.002)$ & $-0.015(0.017)$ \\
\hline Commercial banks & $0.009 * * *(0.002)$ & $-0.03(0.094)$ & $0.007 * * *(0.002)$ & $0.019(0.021)$ \\
\hline Stockbrokers & $0.010 * * *(0.002)$ & $-0.054(0.082)$ & $0.006 * * *(0.002)$ & $0.013(0.015)$ \\
\hline Pension funds & $0.011 * * *(0.003)$ & $0.068(0.139)$ & $0.005 * * *(0.002)$ & $0.011(0.025)$ \\
\hline
\end{tabular}

Source: authors' calculations. All estimations correspond to rolling regressions. Values correspond to $\left(M S P E_{r}-M S P E_{u}\right)$, where $M S P E_{r}$ and $M E S P E_{u}$ correspond to "restricted" (Random Walk) and "unrestricted" (competing strategies) models. Methodology follows that of Clark and West (2006). Standard errors are in parenthesis

$* * *, * *, *$ correspond to significance levels of 1,5 and $10 \%$, respectively

\section{References}

Allen H, Taylor MP (1990) Charts, noise and fundamentals in the London foreign exchange market. Econ J 100:49-59

Ashley, R., C. W. Granger, and R. Schmalensee (1980) Advertising and aggregate consumption: an analysis of causality. Econometrica: Journal of the Econometric Society, 1149-1167 
Baillie RT, Bollerslev T, Mikkelsen HO (1996) Fractionally integrated generalized autoregressive conditional heteroskedasticity. J Econom 74:3-30

Becketti, S., W. Gould, L. Lillard, and F. Welch (1985) The panel study of income dynamics after fourteen years: an evaluation, UCLA Economics Working Papers 361, UCLA Department of Economics

Bekaert G (1996) The time variation of risk and return in foreign exchange markets: a general equilibrium perspective. Rev Financ Stud 9:427-470

Benassy-Quere A, Larribeau S, MacDonald R (2003) Models of exchange rate expectations: how much heterogeneity? J Int Financ Markets Inst Money 13:113-136

Bilson, JFO (1980) The speculative efficiency hypothesis, NBER Working Papers 0474, National Bureau of Economic Research, Inc

Carlson JA (1998) Risk aversion, foreign exchange speculation and gamblers ruin. Economica 65:441-453

Cavaglia S, Verschoor WF, Wolff CC (1993) Further evidence on exchange rate expectations. J Int Money Finance 12:78-98

Cheng TC, Trivedi PK (2015) Attrition bias in panel data: a sheep in wolf's clothing? A case study based on the mabel survey. Health Econ 24:1101-1117

Cheung Y-W, Chinn MD, Pascual AG (2005) Empirical exchange rate models of the nineties: are any fit to survive? J Int Money Finance 24:1150-1175

Chinn M (2007) Interest rate parity 4. Entry Written for Princeton Encyclopedia of the World Economy

Christ CF (1975) Judging the performance of econometric models of the US economy. Int Econ Rev 54-74

Christiano LJ (1989) Not the inflation forecaster's Holy Grail, Federal Reserve Bank of Minneapolis. Quarterly Review-Federal Reserve Bank of Minneapolis 13:3

Clark TE, West KD (2006) Using out-of-sample mean squared prediction errors to test the martingale difference hypothesis. J Econom 135:155-186

Crowder WJ (1994) Foreign exchange market efficiency and common stochastic trends. J Int Money Finance 13:551-564

De Grauwe P, Grimaldi M (2006) The exchange rate in a behavioral finance framework. Princeton University Press, Princeton

De Grauwe P, Markiewicz A (2013) Learning to forecast the exchange rate: two competing approaches. J Int Money Finance 32:42-76

Diebold FX, Mariano RS (1995) Comparing predictive accuracy. J Bus Econ Stat 13:253-263

Dominguez K (1986) Are foreign exchange forecasts rational? New evidence from survey data. Econ Lett 21:277-281

Dominguez KM, Frankel JA (1993) Does Foreign-exchange intervention matter? The portfolio effect. Am Econ Rev 83:1356-1369

Dornbusch R (1976) Expectations and exchange rate dynamics. J Polit Econ 84:1161-1176

Echavarría, JJ, Melo LF, Téllez S, Villamizar M (2013) The impact of pre-announced day-to-day interventions on the Colombian exchange rate, BIS Working Papers 428, Bank for International Settlements

Echavarría JJ, Vásquez D, Villamizar M (2008) Expectativas, tasa de interés y tasa de cambio: paridad cubierta y no cubierta en Colombia, 2000-2007. Ensayos Sobre Política Económica 26:149-203

Engel C (1996) The forward discount anomaly and the risk premium: A survey of recent evidence. J Empir Finance 3:123-192

Evans MD, Lyons RK (2005) Meese-rogoff redux: micro-based exchange rate forecasting. Tech. rep, National Bureau of Economic Research

Fair RC (1979) An analysis of the accuracy of four macroeconometric models. The Journal of Political Economy, 701-718

Fama EF (1984) Forward and spot exchange rates. J Monet Econ 14:319-338

Fama EF, French KR (1988) Permanent and temporary components of stock prices. J Polit Econ 96:246-273

Fitzgerald J, Gottschalk P, Moffitt R (1998) An analysis of sample attrition in panel data: the michigan panel study of income dynamics. J Hum Res 33:251-299

Frankel JA (1979) On the mark: a theory of floating exchange rates based on real interest differentials. Am Econ Rev 69:610-622

Frankel JA, Froot KA (1986) Understanding the US dollar in the eighties: the expectations of chartists and fundamentalists. Econ Rec 62:24-38 
Frankel JA, Froot KA (1987) Using survey data to test standard propositions regarding exchange rate expectations. Am Econ Rev 77:133-153

Frankel JA, Froot KA (1989) Forward discount bias: Is it an exchange risk premium? The Quarterly Journal of Economics, 139-161

Frankel JA, Froot KA (1990a) Chartists, fundamentalists, and trading in the foreign exchange market. American Economic Review, American Economic Association. 80:181-85

Frankel JA, Froot KA (1990b) Exchange rate forecasting techniques, survey data, and implications for the foreign exchange market. Working Paper 3470, National Bureau of Economic Research

Frankel JA, Rose AK (1994) A survey of empirical research on nominal exchange rates. Working Paper 4865, National Bureau of Economic Research

Frenkel JA (1976) A monetary approach to the exchange rate: doctrinal aspects and empirical evidence. Scand J Econ 78:200-224

Friedman M (1953) The case for flexible exchange rates. Essays Posit Econ 1:413-437

Garbers H (1987) A misspecification analysis of the relationship between spot and forward exchange rates. Eur Econ Rev 31:1407-1417

Gourinchas PO, Rey H (2005) International financial adjustment, NBER Working Papers 11155, National Bureau of Economic Research, Inc

Granger CWJ, Newbold P (1977) Forecasting economic time series. Academic Press, New York

Hansen LP, Hodrick RJ (1980) Forward exchange rates as optimal predictors of future spot rates: an econometric analysis. J Polit Econ 88:829-853

Hansen LP, Hodrick RJ (1983) Risk averse speculation in the forward foreign exchange market: an econometric analysis of linear models. In: Exchange rates and international macroeconomics, University of Chicago Press, pp 113-152

Heckman JJ (1979) Sample selection bias as a specification error. Econometrica 47:153-161

Hodrick RJ (1987) The empirical evidence on the efficiency of forward and futures foreign exchange markets, vol. 1, 1 ed, Harwood Academic Publishers GmbH

Hodrick RJ, Srivastava S (1984) An investigation of risk and return in forward foreign exchange. J Int Money Finance 3:5-29

Hodrick RJ, Srivastava S (1986) The covariation of risk premiums and expected future spot exchange rates. J Int Money Finance 5:S5-S21

Hsieh DA (1983) Tests of rational expectations and no risk premium in forward exchange market. J Int Econ 17:173-184

Ito T (1990) Foreign exchange rate expectations: micro survey data. Am Econ Rev 80:434-449

Jongen R, Verschoor WF, Wolff CC (2008) Foreign exchange rate expectations: survey and synthesis. J Econ Surv 22:140-165

Kaminsky G, Peruga R (1990) Can a time-varying risk premium explain excess returns in the forward market for foreign exchange? J Int Econ 28:47-70

Keim DB, Stambaugh RF (1986) Predicting returns in the stock and bond markets. J Financ Econ 17:357-390

Levich RM (1979) On the efficiency of markets for foreign exchange. vol. 1, Johns Hopkins University Press, 1 ed

Lewis KK (1995) Puzzles in international financial markets. In: Handbook of International Economics. ed. by G. M. Grossman and K. Rogoff, Elsevier, vol. 3 of Handbook of International Economics, chap. 37, pp 1913-1971

Litterman RB (1979) Techniques of forecasting using vector autoregressions. Working Paper 115, Federal Reserve Bank of Minneapolis

Lo AW, MacKinlay AC (1987) Stock market prices do not follow random walks: evidence from a simple specification test. NBER Working Papers 2168, National Bureau of Economic Research, Inc

MacDonald R, Taylor MP (1992) Exchange rate economics: a survey. Staff Papers-International Monetary Fund, pp 1-57

MacDonald R, Torrance TS (1990) Expectations formation and risk in four foreign exchange markets. Oxford Economic Papers, pp 544-561

Mark NC, Wu Y (1998) Rethinking deviations from uncovered interest parity: the role of covariance risk and noise. Economic Journal, 1686-1706

Maynard A, Phillips PC (2001) Rethinking an old empirical puzzle: econometric evidence on the forward discount anomaly. J Appl Econom 16:671-708

McCallum BT (1994) A reconsideration of the uncovered interest parity relationship. J Monet Econ 33:105-132 
Meese RA, Rogoff K (1983) Empirical exchange rate models of the seventies : Do they fit out of sample? Journal of International Economics, Elsevier, 14, pp 3-24

Meese RA, Rogoff K (1988) Was it real? the exchange rate-interest differential relation over the modern floating-rate period. J Finance 43:933-948

Meredith G, Ma Y (2002) The forward premium puzzle revisited. IMF Working Papers 02/28, International Monetary Fund

Mussa ML (1979) The theory of exchange rate determination. In: Exchange rate theory and practice, University of Chicago Press, pp 13-78

Nelson CR (1972) The prediction performance of the FRB-MIT-PENN model of the US economy. The American Economic Review, pp 902-917

Nurkse R (1944) International currency experience: lessons of the interwar period, 4, League of Nations

Rogoff K (2009) Exchange rates in the modern floating era: what do we really know? Rev World Econ 145:1-12

Takagi S (1991) Exchange rate expectations: a survey of survey studies. IMF Staff Papers 38:156-183

Villa M (2011) Expectativas y Estabilidad Cambiaria. Son Desestabilizadores los Especuladores en Colombia? Tech. rep., mimeo

Villamizar-Villegas M (2015) Identifying the Effects of Simultaneous Monetary Policy Shocks. Contemporary Economic Policy. doi:10.1111/coep.12111

Villamizar-Villegas M, Perez-Reyna D (2015) A Theoretical Approach to Sterilized Foreign Exchange Intervention. Journal of Economic Surveys. doi:10.1111/joes.12136

Wakita S (1989) Are survey forecasts trusted? Econ Lett 29:339-344

West KD, Edison HJ, Cho D (1993) A utility-based comparison of some models of exchange rate volatility. J Int Econ 35:23-45

Woodford M, Walsh CE (2005) Interest and prices: foundations of a theory of monetary policy. Macroecon Dyn 9:462-468 